Book Review

\title{
Power-sharing Islam?
}

\section{By 'Azzam Tamimi (ed.). London: Liberty Publications, 1993, $192 \mathrm{pp}$.}

This work has ventured to fill a vast gap in contemporary Islamic political thought. By relating relevant basic and secondary sources to contemporary contexts in different countries, it has attempted to determine the extent of harmony and discond between Islamic political theory and current praxis. Being the first English-language publication on this subject inevitably raises the expectations about its scholarly merit.

The first paragraph of the introduction highlights the anomalous consequences of democratization in the Muslim world: reconciliation in some and heightened adversity in others. In principle, democracy can be reconciled with Islamic political thought. The editor then gives an historical outline of misconceptions towand the role of democracy in Islamic politics, which began with the Crusades and were reaffirmed during the Iranian revolution of 1979 . Tuming to the twentieth century, revivalism, which often has explicit political motivations, could be easily traced to the collapse of the Islamic caliphate. It has always welcomed democra- 
tization initially and has expressed its readiness to participate in elections and accept their results. This is an important point, I feel, to dispel notions of absolute fanaticism, bigotry, and despotism levelled against revivalism.

The next three articles provide westem perspectives on power-sharing Islam. Fortunately, John Keane's "Power-sharing Islam?" defines the pejorative term of "Islamic fundamentalism" before clarifying its impact on the westem psyche caused by Muslim migration to multifaith communities in Europe, the Gulf war, and the Bosnian catastrophe. It nonetheless overlooks one dimension: its most reactionary connotation includes any practicing Muslim. Ultimately, such a person is distinguished from the "Muslim" whose level of belief or practice barely rises above the banality of census statistics. Keane adds that some Islamists combat the ideology of Islam-as-fundamentalism by demonstrating Islam's capacity for democracy. He identifies a strategic problem: "the transition to democracy dilemma." An Islamic movement that remains faithful to its own principles and to democracy could have its attempts at achieving political power thwarted by the unethical contrivances of its opponents. Alternatively, an Islamic movement could contemplate undemocratic means purely to attain power and then return to parliamentarism. The latter is fraught with tragic possibilities of political retrogression, whereas the former is more problematic, since it could result in the perpetual marginalization of Islamic movements. He asserts further that with the present global decline of the nation-state's sovereignty, the cores of state power are being increasingly dispersed. A strategy for Islamic forces lies in their operating within civil society. But the results in at least one country he has cited-Egypt-are gloomy (see Al-Erian's article) while those in Malaysia are simply tolerable (see Ali, p. 124).

This automatically raises the question: how empowered is civil society to act as a catalyst for change? The enigma surrounding the universality of Islam receives convincing focus, both in terms of countries where Muslims constitute majorities as well as minorities. Recognition of heterogeneity implies support for nonreligious (or other-religious) institutions. Thereafter, the problem of treating discordant voices within its own body politic is also raised to emphasize a cardinal problem: if Muslims are prepared to share power with others, even if for the sake of expediency, to what extent could they be democratic within their own fold? He then evaluates incompatibilities between Islam and democracy. While Islam operates firmly within divinely-prescribed parameters, presenting itself as a complete way of life, democracy entails freedom from all ideology. In this light, I am inclined to regard an Islamic order as a theocratic democracy (see Al-Alkim's article). Such a qualification, 
nevertheless, negates the granting of any exclusive legislative powers to traditional religious leadership. At this point, one also wonders: are concepts like freedom, democracy, and equality not delimited by power institutions to fulfil their aims anyhow? This objection is raised by Islamic movements also (see Burgat, p. 44).

In comparing the failure of Marxism with the success of Islam, Ernest Gellner (pp. 33-42) postulates three possible reasons: firstly, Marxism is a totally secular religion, whereas Islam has a very strong spiritual component that influences human hearts. In times of distress, Marxism failed to hold sway over the hearts of even some adherents, something that Islam has been able to do for centuries. Secondly, Marxism sacralizes the entire social life, including the economic. While Islam orders social life, it does not fully sacralize it. In other words, it provides its adherents with a sphere of the profane to which they can retreat. Thirdly, the crisis of underdevelopment has led many Muslims to castigate the West while having faith in their own outlook. This outlook is revived constantly by its own high tradition (or fundamentalism), which is characterized by unitarianism and puritanism.

Francois Burgat's article examines "Bilateral Radicalisation." In general, the spiral of violence is initiated by anti-Islamists who obstruct democracy. He examines the cases of Egypt and Algeria to support his view that both the timing of and causes for these confrontations indicate that religion is neither the principal generator of violence and that the latter is not the sole means of articulation for the former. The Algerian election of 1991 actually confirmed the popularity of Islamic groupings, particularly among the majority of women voters. This category was expected to manifest its rebellion against the alleged male domination via Islamic groupings by supporting the ruling, secular, political party.

In his prognosis of democracy in the Arab world, the writer warns both against the ability of individual members of Islamic movements to honor pledges of tolerance issued by their leaders as well as the ability of their opponents to become democrats automatically. He finds that Islamic forces hail from a variety of social bases and subscribe to different programs of action. The common denominator is their desire to be viewed as a legitimate alternative to western hegemony. Such identification of subtle differences is useful for the West in its understanding of Islamic revivalism.

The next three articles provide Muslim perspectives on the question of power-sharing. The last two of these, in particular, pertain to situations in which Muslims constitute the majority. The first one, which features Rachid Ghannouchi on "The Participation of Islamists in a non-Muslim Government," is absorbing reading. Couched in a simple, direct style- 
here the reference is to the translated version-the scholar comments that the divine ordinance regarding the establishment of justice is the cornerstone for participation. In other words, Muslims are obliged to participate in any structures that seek to create or foster justice. He substantiates his views further by invoking the juristic principle of requirements and necessities, arguing that realism and flexibility enjoy ample scope for application within the exceptional circumstances confronted by millions of Muslims. Another pertinent rule from jurisprudence is that all actions are permissible unless decreed otherwise by Allah. Even though all the requirements of the Shari 'ah might not be met, such evils as dictatorship could be averted by such participation. He cites the examples of Prophet Yūsuf, the attitude of the Prophet toward Negus, the hilf al fudūl, and the ruler 'Umar ibn 'Abd al 'Azìz. Finally, he discusses the contemporary situation, in which pragmatism has guided many Islamic individuals and groups to ally themselves with a non-Islamic framework.

Al-Awa defends "Political Pluralism from an Islamic Perspective" by quoting Qur'anic verses related to diversity in creation. He also quotes such juristic principles as ijtihad to deduce the probability of obtaining freedom, equality, the right to enjoin virtue and forbid vice, and guarantees for the accountability of rulers to their subjects through political pluralism. These ethical values are also the fundamentals for an Islamic state. However, this political entity is an illusion for Abdelwahab El-Affendi (see "Who Needs an Islamic State?," p. 93) and Ayubi (see "Political Islam," p. 17). El-Affendi contends that one should speak about a state for the Muslims or an Islamic political community. An Islamic state simply conjures up utopian polity ideals "in which a righteous and saintly ruler will miraculously emerge to restore the long-lost golden age of Islam" (see El-Affendi, p. 93). Returning to Al-Awa, I find the stipulation about all political parties abiding by Islamic values to be idealistic. To achieve this, a state has to be religiously homogeneous, which is unlikely at this point in time.

Hassan Al-Alkim's "Islam \& Democracy: Mutually Reinforcing or Incompatible?," raises some important issues, despite any disagreement one may have on the question of an Islamic state. He declares that Islam favors theocratic democracy. Islamic democracy is at variance with liberal democracy, since the former is a popular suzerainty operating within God's suzerainty. Akbar Ahmed, in his work Postmodernism and Islam (p. 23), has an illuminating comment in this regard. He maintains that although democracy is the most desirable method of conducting human affairs, total democracy is, paradoxically, "the closest thing to total anarchy. In reducing human thought and activity to the lowest common. 
denominator it unleashes forces sometimes difficult to control." So checks and balances have to be instituted.

Al-Alkim then describes the Islamic government as a republic in which the masses are ordered to act according to religious insights into their interests. His association of shürā with the legislature is a sound, novel idea. He outlines similarities between the two systems with reference to elections and checks and balances. During his analysis, the concept of the Muslim community (ummah) is not examined in its sociohistorical sense, giving the impression that its signification of a religious community is obvious. However, such a consensus is not obtainable, as other terms (i.e., millah) have also been used for this purpose (see Ayubi, p. 19 for additional details). He states that the multiparty system is gaining in popularity among Islamic political parties and movements. There shall always be a place for interest groups while minority rights shall be accorded.

The following section examines countries in which Islam's powersharing exercise with regimes has been successful. In Jordan, this experiment has worked for roughly forty years. The author, Al-Akailah, is forthright in his assessment. Each group knows the capabilities and limitations of the other. Peaceful coexistence has characterized their relationship. In relating the Kuwaiti experience, Nasser Sani resembles more a suave politician than an academic. In just five lines, he glosses cursorily over the most important political event in the country's history: the Gulf war of 1991. Surely the autocratic rule of the Al-Sabah family could not have provided such a smooth political leverage to the Islamic movement. The style is conversational, sometimes bordering on the mediocre: "Democracy, as everybody knows, is not something that you can adopt immediately, it is not a suit you go and buy and once you've put it on you become democratic" (p. 103) and "It was not an Islamicallyoriented parliament, so why was it nicknamed the 'Islamic parliament'? This was simply because . . ." (p. 104). In contrast, the Malaysian experience as related by Mustafa Ali makes factual reading. His concluding remarks about the limitations in relations between secularism and Islamic movements are noteworthy: Islamic forces shall at best be tolerated so long as they remain innocuous.

The final section reviews failures in power-sharing enterprises. The first two, by Anwar Haddam and Ben Eissa, discuss the Algerian scenario. Haddam concludes, inter alia, that it would be in the westem interest to portray the Islamic Front for Salvation (FIS) realistically: "Historically, western nations have had better relations with freely elected rulers than with imposed military dictatorships" (p. 139 ff.). Then why the contradiction, one wonders? Certainly, the New World Order's 
attitudes towards legitimate Islamic movements are a good barometer of its integrity. Ben Eissa advocates the recognition of legitimate Muslim demands.

Kamal El-Halbawy's article on Afghanistan is a severe indictment of the Muslim greed and ambition that impede meaningful progress toward power-sharing, while Essam Al-Erian's account of Egypt reiterates the fundamental cause for the collapse of power-sharing to be the lack of true democracy. This comment summarizes effectively the tragedy in all countries where the power-sharing endeavor has failed.

We now focus on some general observations. Unfortunately, there are many typographical errors and inconsistencies in the spelling of certain names. The concern here is not for different transliteration symbols used in English and French for particular Arabic phonemes. Such a problem would probably remain insurmountable. An examination of Arabic bibliographical references reveals this shortcoming most glaringly. A representative sample is provided below: Al-Ghannouchi's name appears without the definite article (pp. 10, 51) while bearing it elsewhere (pp. 49, 172); "Maudoodi" (p. 63) becomes "Al-Maududi" (p. 79); "Ibn Qayim" is misprinted as "Abn Qayim," (p. 63) while "Saddam Hussain" (p. 16) becomes "Saddam Hussein" (p. 47); "Muhammad" is erroneously spelt "Mohammed" (p. 79), "Umar" as "Omar" and "Umayyad" as "Ommiad" (p. 58). Even the Divine Name has not been spared with the misprint "Allaj" (p. 148). Finally, "bloc" has acquired an additional "k" to alter its denotation (p. 140). Generally, the editor has to outline guidelines to contributors for maintaining spelling coherency.

The work could be expanded in the next edition with an article explaining the sociohistorical and religious contexts for the origin and development of the terms dār al Islām, dār al ahd, and dār al harb in order to enable the reader to make a more diachronic study of the evolution of Islamic political theory.

Despite the queries and criticisms raised above, this book confirms admirably the editor's judgment of being "the definitive work on what has become one of the most controversial and challenging issues of our time." By constantly engaging the thinking of the insightful reader, it has set a sound standard in this field.

Yousuf Dadoo

Sub-departments of Arabic and Islamic Studies

Department of Semitics University of South Africa Republic of South Africa 